\title{
MÜSZAKI INFORMATIKAI SZAKMÓDSZERTAN A MODERN OKTATÁSBAN
}

\section{TECHNICAL INFORMATICS METHODOLOGY IN MODERN EDUCATION}

\author{
Gingl Zoltán ${ }^{1}$, Kopasz Katalin²

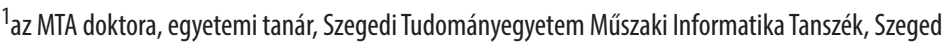 \\ gingl@inf.u-szeged.hu \\ ${ }^{2} \mathrm{PhD}$, adjunktus, Szegedi Tudományegyetem Optikai és Kvantumelektronikai Tanszék, \\ Szegedi Tudományegyetem Gyakorló Gimnázium és Általános Iskola \\ kopaszka@titan.physx.u-szeged.hu
}

\begin{abstract}
ÖSSZEFOGLALÁS
A mai eszközeink döntő többsége már elektronikus, és szoftvereket futtat. A modern technológia a mindennapok része, a tanulók számára is elérhető, aktívan használják a hétköznapi életükben is. Az oktatás komoly kihívás előtt áll, az iskolai közeg nem szakadhat még jobban el a többi életterülettől. Alapvetően fontos, hogy a képzés ne csak felhasználja a modern technológiát, hanem segítse is a diákokat a legalapvetőbb elvek megértésében, erősítse a műszaki pályákhoz szükséges szemlélet elsajátítását, fejlessze a technológia kreatív alkalmazásához nélkülözhetetlen találékonyságot. Ennek támogatására kísérleteket, megoldásokat, oktatási módszereket fejlesztettünk a középiskolai, egyetemi és tanártovábbképzés számára is. Fontos megemlíteni, hogy az oktatás csak akkor tud lépést tartani a fejlődéssel, ha a tanároknak jelentős szabadságuk van a tananyag, az eszközök és az élményszerű tanulási módszerek megválasztásában.

Az új Nemzeti alaptanterv és a hozzá kapcsolódó kerettantervek nehezítik a működési elvek oktatását, amihez nélkülözhetetlen lenne több tárgy tanterveinek az összehangolása. A szakmódszertani kutatásokat végző közösségeknek, a tudományos és oktatási élet szereplőinek fontos feladatuk az is, hogy erőfeszítéseket tegyenek a megfelelő oktatási környezet kialakulásának érdekében.
\end{abstract}

\section{ABSTRACT}

The majority of today's devices are electronic and software operated. Modern technology is a part of everyday life of the students too. Education has a serious challenge concerning this, the school environment must not be separated from other areas of life. Besides using modern technology, education should focus on helping the students to understand the basic principles, developing the correct attitude and ingenuity necessary for the creative application of technology. To support this, we have developed experiments, solutions and teaching methods for secondary school, university and teacher training. It is important to note that education can only keep up with the development if teachers have significant freedom in the choice of curriculum, tools, and experiential learning methods. The new National Core Curriculum and the related framework curricula make it difficult to teach the important principles of operation, for which it would be essential to coordinate the curricula of several subjects. The communities of methodological research, the participants of the scientific and educational life should make efforts in order to create the proper educational environment. 
Kulcsszavak: műszaki informatikai szakmódszertan, MTMI-oktatás, modern technológia az oktatásban, Arduino

Keywords: technical informatics methodology, STEM education, modern technology in education, Arduino

A modern világban az eszközök egyre nagyobb része elektronikus, és szoftvereket futtat. A legkézenfekvőbb példa az okostelefon, de ide sorolhatjuk az automatákat, játékokat, orvosi eszközöket, járműveket is. A tárgyak internete (Internet of Things, IoT), a negyedik ipari forradalom, az ipar 4.0 koncepció is ezekre a megoldásokra épül: a háztartási, ipari, orvosi eszközök egyre önállóbban képesek feladataikat elvégezni, érzékelni és hatást létrehozni, egymással kommunikálni. A robotika kulcsfontosságúvá vált, az elektronizálás és mesterséges intelligencia ma már a mindennapok része. Mindenki számára ismerősen hangzanak az „okoseszköz”, „okosotthon”, „okosváros” elnevezések is. Nyilvánvaló, hogy az oktatás nem maradhat ki ebből a folyamatból, és egyúttal igen nagy kihívás előtt is áll. Valamilyen módon követnie kell a rendkívül gyors változásokat, alkalmazkodnia kell a körülményekhez, ellenkező esetben képtelen lesz betölteni szerepét, amely pedig elengedhetetlenül fontos a fejlödés és megfelelő müveltséggel rendelkező emberek szempontjából.

A modern eszközök, „okos”-eszközök a legmodernebb, sok szakterületet átfogó tudásra épülnek, így joggal feltételezhetjük, hogy egyre inkább „,fekete dobozok". Felmerül a kérdés, hogy vajon érdemes-e egyáltalán törekedni arra, hogy megpróbáljuk megértetni a müködésüket az iskolában? Azt bizonyosan látjuk, hogy egyre több olyan építőelem kerülhet a diákok kezébe, amelyet régebben csak mérnökök, tapasztalt szakemberek használtak: áramkörök, robotok, szoftverek, egyszerüen használható, bankkártya méretủ számítógépek.

Az MTA-SZTE Müszaki Informatika Szakmódszertani Kutatócsoportunk (URL1) egyik fó célja az, hogy segítse azoknak az általános elveknek az oktatását, melyek alapján a modern eszközök müködése megérthető, az MTMI- (matematikai, természettudományos, müszaki, informatikai, STEM) képzés támogatható. Az érzékelés, elektromos jelekké alakítás, digitalizálás, algoritmusok létrehozása, programok írása hasonlóságot mutat az emberi viselkedéssel és gondolkodással, hiszen a modern és hatékony eszközök is egyre inkább az emberi tevékenységet helyettesítik. A diákok a modern eszközök segítségével sokkal közvetlenebbül láthatják az ehhez kapcsolódó elveket és módszereket, hiszen maguk illeszthetik a szenzorokat a parányi számítógépekhez, írhatják meg a müködtető programot, láthatják az eredményt. Élményszerü, gyakorlatias tanulásban lehet részük, fejlödhet a kreativitásuk, számos tantárgy (matematika, fizika, informatika, biológia, kémia, földrajz) ismereteivel és ezek alkalmazásaival is találkozhatnak. 
Kutatócsoportunk egyik fontos területeként kísérleteket, megoldásokat, módszereket keresünk az Arduino-platform oktatási alkalmazásaira. Az Arduino egy tenyérnyi számítógép, amely egy, az iparban is használt áramkörre épül, $\mathrm{C}$ nyelven programozható, mégis könnyen használhatják a diákok a jól kitalált, egyszerü fejlesztői környezetnek köszönhetően. Világszerte rendkívül elterjedt, a Google keresés 146 millió találatot ad, az education vagy school keresőszavakkal együtt is 50 millió körüli az oldalak száma. Megkérdőjelezhetetlenül hasznos és elfogadott az oktatásban, a Physics Education rangos szakmódszertani folyóiratban évről évre növekszik a közlemények száma, amelyekben bemutatják, hogy különböző fizikai kísérletek elvégzéséhez hogyan használható a platform. Az előnyök mellett ugyanakkor hátrányokkal is szembesülhetünk. Mivel rengeteg receptszerủ leírás található az interneten, könnyen reprodukálható, megépíthető számos látványos eszköz és kísérlet. Ez első ránézésre egyértelmüen pozitív, ugyanakkor nem feltétlenül ösztönzi kellően a diákot arra, hogy maga találja meg a megoldásokat. Ha nem elegendő mélységben érti meg a müködést, a hibákat nem megfontolt módon, hanem véletlenszerủ próbálkozásokkal igyekszik kijavítani, az az MTMI-oktatásban és a megfelelő attitüd kialakításában kimondottan káros. Az útmutatók többségét nem felkészült és müszaki területen képzett szakemberek töltik fel, így gyakran látni bár működőképes, de szakmailag kifogásolható megoldásokat, hibás elveket. Ez nagyon megnehezítheti az igényes szemlélet és a megfelelő hozzáállás kialakítását, amelyek pedig fontos alapját képezik a müszaki és természettudományos pályáknak is.

Az utóbbi két évben számos közleményünk jelent meg az Arduino-platformhoz és MTMI-oktatáshoz köthető témákban (URL1). Ezekben részletesen elemeztünk módszereket, megmutattunk olyan helyes metodikát, melyet hiánypótlónak tartunk a fentebb említett okok miatt. Kifejlesztettünk egy olyan kiegészítő áramkört, szoftvert és módszert is, mely átláthatóvá és könnyűvé teszi a legalapvetőbb szenzorok, jelfeldolgozási megoldások, mérési módszerek alkalmazását (Gingl et al., 2019a,b). Fontos célunk, hogy ne mentesítsük a diákot a megértésre törekvés alól, ezért a müködési módot és beállításokat neki kell megválasztania, amihez megfelelő szintü szakmai ismeretekre van szüksége. Az eszközt sokféle kísérlet bemutatására használtuk nemzetközi konferencián tartott workshopok keretében is, számos középiskolában segíti az oktatási feladatok elvégzését. A Szegedi Tudományegyetem Gyakorló Gimnázium és Általános Iskola műszaki informatika orientációjú csoportjának órarendjébe építve hoztunk létre egy fizikai mérések nevü tárgyat. Ezen óra keretében tizedik és tizenkettedik évfolyamon a tanulók heti rendszerességgel végeznek laboratóriumi gyakorlatot, munkájukról jegyzőkönyvet készítenek, amelyet feltöltenek az iskola elektronikus rendszerébe. A diákok a tizedik osztályban megismerik a számítógépes mérések elvi alapjait, bizonyos szenzorok müködési elveit, méréseik során pedig elmélyíthetik fizikai ismereteiket is. Tizenkettedikben elektromosságtani mérési gyakorlatok során 
szereznek jártasságot az áramkörök építésében, majd Arduino-integrált fejlesztői környezetet használva írnak programokat, és építenek modulokat. A tanév végére projektmunka keretében önálló ötleteket valósítanak meg. Makón, a József Attila Gimnáziumban folyó tehetséggondozó munka keretében csoportunk tanár kollégája, Trauer János készített laboratóriumi gyakorlatokat és részletes útmutatókat. Ezek mellett több tanár is csatlakozott munkánkhoz, és folyamatos önképzés mellett keresi annak lehetőségét, hogy a szakkörök mellett hogyan tudja a tanórai keretek között is felhasználni a modern eszközöket és módszereket.

A 2019-es évben négy cikket közöltünk a Physics Education folyóiratban, amely nemzetközi szinten is az egyik legfontosabb fóruma a középfokú fizika tanításának. A cikkekre érkezett átlagos hivatkozási szám a folyóiratra jellemző értékhez közeli, de ennél fontosabb értékmérő lehet a letöltések száma. A folyóirat olvasóinak jelentős része ugyanis középiskolai tanár, akik célja nem cikkek írása, hanem a közvetlen oktatási hasznosítás. A közleményeknél összességében nyolcszáz körüli, egy esetében pedig háromszáz feletti a letöltések száma, ami az átlagos szintnél jelentősen nagyobb érdeklődést mutat.

Felmerül a kérdés, hogy vajon miképp segíthetik a hazai képzést a modern müszaki informatikai eszközök és a kapcsolódó kutatások, eredmények? Nemzetközi téren az oktatásban elterjedten használnak ilyen megoldásokat, külön oktatási célra is készültek eszközök (például: Micro:bit, Raspberry PI egylapos számítógépek, Lego-robotok, az MIT (Massachusetts Institute of Technology) által fejlesztett Scratch). Ezek alkalmassága nyilvánvaló, folyamatosan jelennek meg róluk új írások többek között a Physics Education folyóiratban is.

Alapvetően fontosnak tartjuk, hogy a tanárok hozzájuthassanak alkalmazási példákhoz, a nekik szánt folyóiratok bírálói által megfelelőnek ítélt közleményekhez, legyen lehetőségük ezeket tanórák keretében felhasználni, és ehhez minél több támogatást kapjanak. A tanároknak munkaidejük keretében kell módot biztosítani arra, hogy megismerhessék az új eszközöket és alkalmazásaikat. Támogatni kell azt is, hogy részt vehessenek színvonalas tanártovábbképzéseken, könnyen hozzáférhessenek megfelelö tananyagokhoz. Az MTMI-szakterület igen gyorsan változik, rendszeresen jelennek meg újdonságok, amit megfelelően követni csak akkor lehet, ha a tanároknak jelentős szabadságuk van annak megválasztásában is, hogy mit és hogyan tanítanak, milyen segédanyagot használnak. Az MTMI-pályák népszerüsítése szempontjából fontos az is, hogy a modern eszközök és azok használatának élményszerủ tanulási módszerei ne csak az emelt szintü képzésekben és a kiemelkedőbb intézményekben jelenjenek meg, hanem minden iskolatípusban és az ország bármely iskolájában elérhetőek lehessenek. A 2020-ban megjelent Nemzeti alaptanterv és a hozzá kapcsolódó kerettantervek megnehezítik azt, hogy a gimnáziumi oktatásban is hangsúlyt kaphassanak az alapvető elektronikai ismeretek és az informatika müszaki oldala. A digitális kultúra tárgyban ugyan megjelenik a robotika és a programozási alapismeretek té- 
maköre is, de az az MTMI-oktatásban fontos elv valójában háttérbe szorul, hogy az eszközök müködési elve is megérthető. Utóbbihoz a fizika, a matematika és az informatika tantervek összehangolása is nélkülözhetetlen. Az Edaquino-fejlesztésünk lényege pedig éppen az, hogy a fizikatanítás során a szenzorok müködésének megértése és az eszközök értő alkalmazása kerüljön előtérbe, míg az informatika/digitális kultúra órán ugyanazon eszközzel lehessen az algoritmustervezést és a programozást gyakorolni. Az általunk is használt, kellően kiépített, oktatási célokra alkalmas Arduino-platform költsége nagyjából $10000 \mathrm{Ft}$, amiből jól látszik, hogy az iskolák és diákok ellátása nem jelentene semmilyen anyagi problémát.

Nemzetközi és saját tapasztalatok alapján az Arduino-használat arra is lehetöséget adhat, hogy az alapozó ismeretek elsajátítása után a tanulók önálló projekteket is megvalósítsanak, és egymást segítve, kooperatív módon is alkothassanak. Utóbbiak a játékélmény okozta belső motiváció növelésén túl fejleszthetik a tanulók önálló gondolkodását és problémamegoldási kompetenciáját, az egymás iránti felelősségvállalást is, ami elengedhetetlen ahhoz, hogy a diákok sikeresek legyenek az MTMI-pályákon. A szakmódszertani és kapcsolódó kutatásokat végző közösségeknek, az egyetemi oktatóknak, iskolai tanároknak, az MTA kutatóinak fontos feladata, hogy szakmai munkájuk mellett közösen, egymás munkáját figyelemmel kísérve és kapcsolatot tartva minél több erőfeszítést tegyenek azért is, hogy a megfelelő oktatási környezet kialakulhasson.

A tanulmány elkészítését a Magyar Tudományos Akadémia Tantárgy-pedagógiai Kutatási Programja támogatta.

IRODALOM

Gingl Z. - Makan G. - Mellár J. et al. (2019a): Phonocardiography and Photoplethysmography with Simple Arduino Setups to Support Interdisciplinary STEM Education. IEEE Access, 7, 88970-88985

Gingl Z. - Mellár J. - Szépe T. et al. (2019b): Universal Arduino-based Experimenting System to Support Teaching of Natural Sciences. Journal of Physics: Conference Series, 1287012052

URL1: Miszak - MTA-SZTE Müszaki Informatika Szakmódszertani Kutatócsoport. http://www. inf.u-szeged.hu/miszak/ 